\title{
CORPORATIONS IN INTERNATIONAL LITIGATION: PROBLEMS OF JURISDICTION AND THE UNITED KINGDOM ASBESTOS CASES
}

\author{
Peter MuchlinsKi*
}

IN his seminal work The Multinational Challenge to Corporation Law Professor Phillip Blumberg assets that, "jurisdiction continues to be one of the most litigated areas involving the clash of enterprise and entity." Indeed, in a world where business is increasingly conducted through the medium of economically integrated multinational enterprises (MNEs), the question of whether a forum has jurisdiction over disputes arising out of the operations of non-resident entities of the MNE brings into contrast the mismatch between the territorial reach of the legal system and the transnational reach of the enterprise. In terms of corporation law this raises the further matter of whether, and how far, the legal organisation of the MNE into distinct legal entities, in distinct legal jurisdictions, should affect the applicable rules of private international law as to the reach and scope of forum jurisdiction. Such issues have recently been aired before the English courts in a series of cases, arising out of the asbestos mining and milling operations of the British based MNE Cape plc in South Africa, which culminated in a judgment given by the House of Lords on 20 July 2000. It is the purpose of this paper to explore the issues of jurisdiction over non-resident entities of MNEs, first, through an examination of these cases in the light of Cape's industrial and management structure. It is striking how little such matters are addressed in the Anglo-American legal literature pertaining to private international law. ${ }^{2}$ Rather than considering the economic realities of the cases in issue, and developing new doctrines to deal with them, lawyers have tended to rely on legal concepts - in particular, the territorial nature of legal jurisdiction and the single unit corporate form - to lead them to often unsatisfactory results that would appear to a lay person not to accord with justice. A

\footnotetext{
* Drapers' Professor of Law, Queen Mary and Westfield College, University of London. An earlier draft of this article was presented as a paper at the ILA 2000 Conference, London, 28 July 2000. Many thanks to Richard Meeran and Susannah Read for their valuable help and insights. Errors or omissions remain my responsibility alone.

1. Phillip I. Blumberg, The Multinational Challenge to Corporation Law (Oxford, Oxford University Press, 1993) at p.117.

2. But see Blumberg op. cit. note 1 at pp.116-7, 197-99; P.T. Muchlinski, Multinational Enterprises and the Law (Oxford, Blackwell Publishers, revised paperback edition, 1999) chaps.3 and 5 and Janet Dine, The Governance of Corporate Groups (Cambridge, Cambridge University Press, 2000) chap.3.
} 
clearer understanding of the economic realities of group operations thus seems essential for the development of law in this area.

Secondly, the Cape litigation is occurring in a legal system that is at once a common law jurisdiction, applying in particular the forum non conveniens doctrine, and a Member State of the European Union (EU), which has resulted in a degree of harmonisation in the field of jurisdiction through the European Community Convention on Jurisdiction and the Enforcement of Judgments in Civil and Commercial Matters (the Brussels Convention). ${ }^{3}$ This has raised the wider question of whether, in the light of the principles of the Brussels Convention, the forum non conveniens doctrine should continue to be available. Although the House of Lords did not come to a final conclusion on this matter, it will be discussed in the present paper as the Brussels Convention approach may be of value in personal injury litigation involving English based MNEs and foreign claimants. This discussion has to be read in the light of the continuing negotiations for a multilateral convention on civil jurisdiction and judgments under the auspices of the Hague Conference on Private International Law, where the issue of whether the doctrine of forum non conveniens should continue has been hotly debated. ${ }^{4}$ The argument of the present paper is that, in relation to transnational litigation involving MNEs and personal injury claimants from host countries, this doctrine may cause significant injustice by denying to the claimant, as the weaker party, a choice of jurisdictions between the host country where the harm occurred and the home country where the principal place of management of the MNE is located.

The paper is divided into four sections. The first section will briefly describe the UK asbestos litigation before the lower courts and identify the principal legal issues that it has raised. The second section will consider the economic and industrial organisation context of the litigation. The third section of the paper will then examine the main legal issues, and how they were approached by the House of Lords, in the light of this analysis, and the summary and conclusions will suggest ways forward that will be able to balance the needs of justice for claimants alongside the interests of MNEs.

3. This Convention was signed in 1968 and came into force in 1973 . The original version can be found in O.J. [1978] L304/77. For the more recent Consolidated version of the Convention see O.J. [1998] C27/1. Similar principles are extended to EFTA countries through the Lugano Convention 1988. For comment on the jurisdictional issues see P.M. North and J.J. Fawcett Cheshire and North's Private International Law (London, Butterworths, 13th ed, 1999) chaps.11-14. The Brussels Convention has the force of English law through the Civil Jurisdiction and Judgments Act 19821982 c.27. See L. Collins The Civil Jurisdiction and Judgments Act 1982 (London, Butterworths, 1983).

4. See Cheshire and North ibid. at p.284. See too the Hague Preliminary Draft Convention on Civil Jurisdiction and Enforcement of Judgments, Article 22 http://www.hcch.net/e/workprog/jdgm.html 


\section{(1) The Cape Cases Before the Lower Courts}

The litigation arose out of a series of claims brought against the parent company by employees of its Southern African subsidiaries and by claimants who lived in the vicinity of facilities operated by those subsidiaries. ${ }^{5}$ The claimants alleged that they had suffered serious injury to their health by reason of their exposure to asbestos dust caused by the negligence of the defendant company in the conduct of their asbestos mining and milling activities. In addition, another action was commenced by writ on 3 October 1997 by four Italian claimants who are claiming damages for personal injury suffered while working in or living near the Turin factory operated by the defendant company. That action could not be stayed as the defendant company was domiciled in England and so was rightly sued by Italian claimants in an English court in accordance with Article 2 of the Brussels Convention. ${ }^{6}$

Given that Cape plc was domiciled in England, there was no dispute over whether it had been properly served or that the court had personal jurisdiction. Thus the dispute turned on the issue of the appropriateness of the English, as opposed to the South African, forum. This depended on the application to the facts of the forum non conveniens doctrine as developed in Spiliada Maritime Corporation v. Cansulex $\mathrm{Ltd}^{7}$ and its subsequent case-law. ${ }^{8}$ There are two requirements under this doctrine. First, the defendant, who is sued as of right before the English forum,

5. Lubbe et al. v. Cape plc (CA 30 July 1998) [1998] C.L.C. 1559; Group Action Afrika et al. v. Cape plc (QBD 30 July 1999) [2000] 1 Lloyd's Rep. 139 at 141; Rachel Lubbe et al. v. Cape plc (CA 29 Nov. 1999) [2000] 1 Lloyd's Rep. 139 overturned on appeal before the House of Lords Schalk Willem Burger Lubbe et al. v. Cape plc. Judgment 20 July 2000 http://www.parliament.the-stationery-office.co.uk/pa/ld 199900/ldjudgmt/jd000720/ lubbe-1.htm. [2000] 2 Lloyds Reports 383. See too Durham v. T \& N plc (CA 1 May 1996 unreported) for a similar case involving a claim by an employee in a Canadian subsidiary of an English-based parent. The Court of Appeal held that Canadian Law applied to the tort. In Feb. 1999 further proceedings were commenced against T \& N by two South African and two Indian employees. Another set of similar cases have involved the U.K. based firm Thor Chemicals. In this case employees in South Africa sued on the ground of death and personal injury suffered while exposed to dangerous mercury-based chemical manufacturing processes that had been moved there from the U.K. after English health and safety inspectors had criticised Thor over the effects of these processes on the health of their U.K. employees. See Ngcobo v. Thor Chemical Holdings Ltd (CA 9 Oct. 1995 unreported). Thor Chemicals settled the initial claims against them in 1997 for $£ 1.3$ million. A further 21 claims are now in progress. In July 1998 Thor's attempt to stay these proceedings was rejected by Garland J and leave to appeal was refused by the Court of Appeal: Sithole et al. v. Thor Chemicals Holding Ltd and another (31 July 1998 unreported). For background see Richard Meeran "The Unveiling of Transnational Corporations: A Direct Approach" in Michael Addo (ed.) Human Rights and the Responsibility of Transnational Corporations (The Hague, Kluwer Law International, 1999) pp.161-170.

6. Article 2 states: "Subject to the provisions of this Convention, persons domiciled in a Contracting State shall, whatever their nationality, be sued in the courts of that State".

7. [1987] A.C. 460.

8. See Cheshire and North op. cit. n.3 at pp.334-50 and Connelly v. RTZ plc [1998] A.C. 854, [1997] 4 All E.R. 335 (HL). 
must show that there is another available forum, which is clearly or distinctly more appropriate than the English forum, in that the case may be tried more suitably there in the interests of all the parties and the ends of justice. Secondly, should the defendant discharge this burden by showing that there is some other available forum that is prima facie more appropriate for the trial the court will normally grant a stay unless the claimant can show that, even though there are factors connecting the proceedings with the foreign forum, substantial justice will not be obtained in the foreign jurisdiction. This burden goes beyond merely showing that the claimant will enjoy procedural advantages, or a higher scale of damages or more generous rules on limitation if he or she sues in England in that the claimant takes the foreign forum as they find it, even if it is in some respects less advantageous than the English forum. The claimant must establish that substantial justice will not be done in the otherwise appropriate forum. ${ }^{9}$

The claimants argued that England was the proper forum on the principal ground that Cape plc, the controlling parent of the group that included the South African and Italian subsidiaries, was itself directly responsible for the breaches of the duty of care owed to the classes of person that included the individual claimants. Cape plc sought to have the English action stayed in favour of the South African forum. The defendant company claimed that South Africa was the proper forum as the claimants suffered their principal injuries there in consequence of physical conditions there. Furthermore, the relevant factual allegations were based in South Africa and convenience dictated that the trial should take place there. In addition, South African law governed the question of whether the defendant owed the duty of care alleged by the claimants. Moreover, the South African forum was an "available forum" for the claimants as the defendant was willing to submit to its jurisdiction.

The judicial response to the arguments of the parties was mixed. In the 1998 Court of Appeal judgment in Lubbe et al. v. Cape plc ${ }^{10}$ it was held, overturning the decision at first instance, that, given the English domicile of Cape and given that the defendant company was alleged to have controlled the operation of the mines and mills in South Africa, the alleged breaches of duty occurred essentially in England, although their effects were felt by claimants in South Africa. ${ }^{11}$ By contrast, the subsequent cases before the lower courts all went the other way and a stay of the English proceedings was ordered in favour of the South African forum.

9. Spiliada Maritime Corporation v. Cansulex Ltd op. cit. n.7 at pp.476-82; Connelly v. RTZ [1998] A.C. 854 at pp.871-3; see too Schalk Willem Burger Lubbe v. Cape plc op. cit. n.5 per Lord Bingham at p.390.

10. Op. cit. n.5 Evans, Millett and Auld LJJ.

11. The defendant's petition to the House of Lords was refused on 14 Dec. 1998. 
This approach appears to have been significantly coloured by the apparent judicial disapproval of the handling of the claimant's case by their solicitors. Thus both Buckley $\mathbf{J}$ at first instance ${ }^{12}$ and the Court of Appeal in its second decision ${ }^{13}$ placed considerable weight on the fact that it was only after the favourable decision on jurisdiction in the first Court of Appeal decision, a case involving five claimants, that the claimants' solicitors instituted, on 18 January 1999, a writ on behalf of Hendrik Afrika and 1538 others, which was the subject of the second appeal. Although the defendant's resulting claim to strike out the action for abuse of process was rejected, their Lordships held that the institution of a group action was a sufficient change of circumstances to allow the Court to reconsider its earlier view on jurisdiction. ${ }^{14}$ Indeed, it was this change of circumstances that led the Court of Appeal to depart from its earlier ruling and to endorse the view of Buckley $\mathrm{J}$ that no injustice would be done to the original five claimants in the Lubbe case if they had to bring their action in the same forum as the group action claimants.

The second Court of Appeal ${ }^{15}$ unanimously held that, in addition to the size of the action, all the relevant factors pointed towards a South African forum. It then went on to consider what it called the "public interest" factor. In this their Lordships were introducing into English law an American concept applied in U.S. forum non conveniens cases. In the course of his judgment Buckley $\mathrm{J}$ referred to the U.S. proceedings arising out of the Bhopal gas plant disaster of $1984 .{ }^{16}$ In that case the U.S. courts had concluded that India was the proper forum for the hearing of the claims of the Indian victims on the grounds inter alia that India had the stronger regulatory interest in dealing with the litigation. Following Buckley $\mathbf{J},{ }^{17}$ the Court of Appeal held that the general approach of the Bhopal case appeared apt in the context of personal injury litigation such as the present. These actions concerned operations conducted in South Africa and were concerned with their effect on persons employed and resident there. ${ }^{18}$

12. Op. cit. n.5.

13. Ibid. Pill, Aldous and Tuckey LJJ.

14. See Rachel Lubbe et al. v. Cape plc op. cit. n.5 at p.165 per Pill LJ. See too per Aldous LJ at pp.166-7 who held that the Court of Appeal had been misled as to the nature of the action before them. See too the judgment of Buckley $\mathrm{J}$ in Group Action Afrika et al. v. Cape plc op. cit. n.5 at pp.143-4.

15. Op. cit. n.5.

16. See In re Union Carbide Corporation Gas Plant Disaster at Bhopal India in December 1984634 F.Supp 842 (SDNY 1986) affirmed on appeal 809 F.2d 195 (2nd Cir. 1987). For analysis see P.T. Muchlinski "The Bhopal Case: Controlling Ultrahazardous Industrial Activities Undertaken by Foreign Investors" 50 MLR 545 (1987). Buckley J also referred to Gulf Oil v. Gilbert 330 U.S. 501 (1947); Piper Aircraft v. Reyno 454 U.S. 235 (1981); Richardson-Merell Inc 545 F.Supp 1130 (1982). Only the Bhopal case was referred to by the Court of Appeal.

17. Group Action Afrika et al. v. Cape plc op. cit. n.5 at pp.154-5.

18. Rachel Lubbe et al. v. Cape plc op. cit. n.5 at p.161 per Pill LJ. 
Finally the Court of Appeal considered the nature of the South African forum and the question of legal representation there. Their Lordships rejected any notion that South Africa was an inappropriate forum on this ground, in that it possessed a legal system of high repute. ${ }^{19}$ Furthermore, Tuckey LJ stressed that while the Court could take into account the fact that the foreign forum only had jurisdiction because the defendant had submitted to it, this should not be elevated into some free-standing ground for rejecting foreign forum if it was otherwise more clearly appropriate. ${ }^{20}$ On the matter of legal representation, the claimants had argued that they would be unable to obtain legal aid for the action in South Africa. They had relied on the recent decision of the House of Lords in Connelly v. RTZ Corporation. ${ }^{21}$ In that case the House of Lords held, ${ }^{22}$ inter alia, that under the Spiliada doctrine, as a general rule, the lack of financial assistance in an appropriate foreign forum would not lead to a refusal to grant stay in English proceedings. However, exceptionally, it might be a factor. It depended on the claimant being able to prove that substantial justice would not be done in the appropriate forum where no financial assistance was available. ${ }^{23}$ In the light of this case, the claimants argued that they had legal aid for the English action and that the finding of Buckley $\mathrm{J}$, that in all the circumstances he could not find that legal aid would not be granted if applied for in South Africa, should be reversed. They presented new evidence showing that legal aid was no longer available in South Africa for personal injury actions, as from 1 November 1999. Furthermore, although contingency fees were now available in South Africa, there was conflicting evidence as to whether counsel and attorneys would be prepared to act against the defendants on this basis. ${ }^{24}$ Despite these new developments the Court of Appeal held that this was not a proper case in which to apply the exceptional principle established in Connolly v. RTZ. ${ }^{25}$

The claimants appealed to the House of Lords against this second Court of Appeal decision while the defendants appealed against the decision of the first Court of Appeal. In the event the claimants' appeal was successful and the stay of English proceedings was removed. From this review of the Cape cases, a number of questions arise for further discussion. First, how far should the domicile of the defendant corporation determine the issue of venue? This is particularly important in that

19. Ibid. at pp.162 per Pill LJ.

20. Ibid. at p.168.

21. [1998] A.C. 854.

22. Lords Lloyd of Berwick, Hope of Craighead and Clyde agreed with Lord Goff, Lord Hoffmann dissenting.

23. [1998] A.C. 854 at $873 \mathrm{E}$.

24. Rachel Lubbe et al. v. Cape plc op. cit. n.5 at p.163-4.

25. Ibid. at p.164 per Pill LJ. 
it raises the matter of whether English law should continue to treat cases involving claimants from non-Brussels Convention countries differently from cases involving claimants from Brussels Convention countries. Secondly, what weight should be given to evidence concerning the management and economic organisation of the MNE when determining the appropriateness of the forum? This raises a number of related issues. In particular, how should this evidence be presented and assessed? Furthermore, what standard of proof of corporate organisation is required and what procedural implications does this have? Moreover, the Cape cases raise certain concerns in relation to the "equality of arms" between individual claimants on the one hand and MNEs on the other. Finally, how does the organisation of MNEs impact on the issue of public interest factors? Are home States able to avoid litigation simply by pointing to the regulatory interest of the host State where the alleged tort occurs? These questions will be analysed in more detail in section three of this paper, in the light of the House of Lords ruling. First, attention must turn to the issue at the core of this discussion, namely, the nature of the industrial and managerial organisation of Cape.

\section{(2) The Industrial and Managerial Organisation of Cape}

The starting point for analysis is the definition of MNEs used by economists. ${ }^{26}$ Thus Professor Dunning defines a MNE as, "an enterprise that engages in foreign direct investment (FDI) and owns or controls value-adding activities in more than one country" ${ }^{27}$ This identifies the economic boundaries of the MNE by reference to ownership or control. Thus any economic enterprise in which there is a controlling entity that crosses borders can be a MNE. Hence transnational networks and strategic alliances, which may appear in legal terms as partnerships, franchise chains, consortia or joint venture companies, may also be regarded as MNEs. ${ }^{28}$ This is echoed in the recently revised OECD Guidelines on Multinational Enterprises which state that such enterprises:

[U]sually comprise companies or other entities established in more than one country and so linked that they may co-ordinate their operations in

26. For a fuller analysis see Muchlinski op. cit. n.2 chaps. 2 and 3.

27. J.H. Dunning, Multinational Enterprises and the Global Economy (Wokingham, Addison-Wesley Publishing Co, 1993) p.3. See for similar definitions Neil Hood and Stephen Young, The Economics of Multinational Enterprise (London, Longman, 1979) p.3; Richard Caves, Multinational Enterprise and Economic Analysis (Cambridge, Cambridge University Press, 2nd ed, 1996) p.1.

28. See further Blumberg op. cit. n.1 chap.10, Muchlinski op. cit. n.2 chap.3; Gunther Teubner Law as an Autopoietic System (Oxford, Blackwell Publishers, 1993) chap.7, Teubner "The Many Headed Hydra: Networks as Higher Order Collective Actors" in J. McCahery, S. Picciotto and C. Scott Corporate Control and Accountability (Oxford, Clarendon Press, 1993) p.41. 
various ways. While one or more of these entities may be able to exercise a significant influence over the activities of others, their degree of autonomy within the enterprise may very from one multinational enterprise to another. Ownership may be private, state or mixed. ${ }^{29}$

The Guidelines appear to go further than the economists' definitions in that they emphasise co-ordination rather than control, and stress that different degrees of autonomy might be enjoyed by affiliates.

The corporate defendant in the asbestos cases is Cape plc. ${ }^{30}$ This company has been involved in the mining of asbestos in South Africa since 1893, when its predecessor, the Cape Asbestos Co Ltd was established as a consortium for such purposes. That company ran the South African operations and appointed local directors who acted under regulations drawn up by the English parent. In 1894 Cape Asbestos acquired an Italian factory near Turin to manufacture goods made from blue asbestos mined in South Africa. From 1899 to 1968 Cape Asbestos operated a number of factories in England engaged in processing asbestos and manufacturing asbestos products. In South Africa two new companies, Egnep Ltd and Amosa Ltd were registered in 1916 to exploit brown asbestos deposits mined in Penge, called after the London suburb. These were acquired in 1925 by Cape Asbestos. After World War II the demand for asbestos increased. Up to 1948 the Cape Asbestos Co directly controlled its mining and milling operations in South Africa. In that year a reorganisation took place. Two new companies were formed: Cape Asbestos SA (Pty) Ltd, a subsidiary of the Cape Asbestos Co, and Cape Blue Mines (Pty) Ltd to acquire the Cape Blue mining assets. The various mines operated by this group were sold off in 1979. The claimants alleged that their injuries had been sustained during the period of operations of these mines.

Cape claimed that the reorganisation in 1948 resulted in the cessation of its predecessor's control of operations in South Africa and the resumption of total control, and hence of legal responsibility, by Cape Asbestos SA (CASAP). Thus the day-to-day control of each mine was said to be entirely in the hands of local management. The claimants disputed this by pointing to the fact that a Mr Riley, a member of the Board of the Cape Asbestos Co, had come out from London to take up a permanent appointment in charge of all the South African operations and had reorganised the management of the operation from a single base in Johannesburg. In addition, the claimants adduced further evidence of

29. OECD Guidelines for Multinational Enterprises 27 June 2000 "Concepts and Principles" p.3. http://www. oecd.org/daf/investment/guidelines/mnetext.htm

30. The following paragraph draws on the description of Cape plc in the judgment of Evans LJ in Lubbe et al. v. Cape plc (CA 30 July 1998). See too House of Lords op. cit. n.5 judgment of Lord Bingham at p.387. 
control showing that Cape did indeed have extensive managerial ties with its South African operations. For example, inter alia, directors of the Board of CASAP were often long-serving members of Cape Asbestos; the CASAP Board was appointed by the Managing Director and Chairman of the defendant in consultation with the Chairman and Managing Director of CASAP; the Boards of the operating subsidiary companies were made up of a few directors, mainly directors of the defendant and CASAP; group accounts were prepared between 1947 and 1998; the defendant Board approved the budget of CASAP and the operating subsidiaries and controlled the capital expenditure for both; Group Instructions were issued by the defendant from Head Office on health and safety matters including asbestosis; the Central Research Laboratory at Barking co-ordinated research into asbestos on behalf of the group which specifically included the South African mines and mills; instructions for the purchase of safety equipment were co-ordinated by the defendant's Head Office on behalf of the group. ${ }^{31}$

Economic analysis may help in determining this issue, in that empirical studies show that there appear to be certain patterns of business organisation among MNEs that tend towards greater or lesser integration of management and control. ${ }^{32}$ The findings have concentrated on two sets of factors: first, the general influences on the locus of decision taking and, secondly, the degree of influence commonly exercised by the parent in relation to particular types of decisions. As to the first, after an extensive review of significant empirical studies, the OECD offers the following conclusions:

... a foreign subsidiary may be seen as having relatively little autonomy if it belongs to a large multinational group established in many foreign countries; if it manufactures fairly standardised products; if the activities of the members are largely integrated, with important interflows of products between them (this holds true especially for the investment and finance function); if it has been created to serve a market larger than the country in which it is established; or if the parent company holds a large portion of the equity. On the other hand, a subsidiary may be seen as more autonomous if it was acquired to serve mainly the local market; if it belongs to a small group; if it has interchange of products with the rest of the group and is operating in an activity slightly different from that of other members (the

31. See further House of Lords, Claimant's Final Served Case pp.132-5 points 1-20.

32. See further: OECD Structure and Organisation of Multinational Enterprises (Paris, 1987); Dunning op . cit. n.27 at pp.222-232; Martinez and Jarillo "The Evolution of Research on Co-ordination Mechanisms in Multinational Corporations" 20 Journal of International Business Studies 489 (1989). On control over decision making in UK subsidiaries of foreign-owned firms see: M. Steuer et al. The Impact of Foreign Direct Investment on the United Kingdom (Dept of Trade and Industry, 1973) Ch.7; S. Young, N. Hood and J. Hamill Decision-making in Foreign Owned Multinational Subsidiaries in the UK ILO Working Paper No.35. (Geneva, ILO, 1985). 
opposite holds true for the marketing function); if an important part of its common shares is held by local investors; and if the whole concern pursues a growth strategy. ${ }^{33}$

To these factors may be added: the nationality and resulting business culture of the parent (for example there is some evidence to suggest that U.S. firms tend to be more centralised than non-U.S. firms); the age of the subsidiary, in that centralisation may decrease over time; the method of entry into the host State, in that a new establishment may be more closely controlled than an acquired local company; the industrial sector in which the firm operates, in that some industries will be more globally integrated and centralised than others; the performance of the subsidiary, in that poor performance increases central control; and the tendency of geographically organised MNEs to be less centralised than functional, product or matrix-organised firms. ${ }^{34}$ As to the second, Professor Dunning points out that centralised decisions are more likely in areas that are: "perceived as being culture free, in those which offer substantial economies of common governance, and those which are likely to be more efficiently implemented by the parent firm". He cites R\&D, capital expenditure plans and dividend policy as examples. By contrast, decisions confined to the affiliate, or matters needing sensitivity to local environments and relationships, such as personnel and labour relations or sales promotion, are likely to be made on a decentralised basis. ${ }^{35}$

On the basis of such economic analysis, it is highly likely that Cape was an integrated group enterprise as alleged by the claimants. Indeed, Evans LJ noted in the first Court of Appeal decision:

At this point, it seems to me, the international nature of the defendant company's alleged interests becomes relevant. It is said to have started asbestos production facilities in Italy and in this country and to have marketed the products worldwide. This was of no concern to individuals in South Africa or to others who may or may have not suffered in other countries. But the allegations which the plaintiffs make in this action, and likewise the plaintiffs in the Italian action, are directed to what the defendants did here. It seems to me that this is an important factor to take into account when deciding whether the defendants have discharged the burden of persuading the Court that precedence should be given to the overseas jurisdiction from which the particular individual plaintiffs come.

Thus the Court of Appeal gave weight to the nature of the enterprise carried on by Cape as a factor in coming to their decision.

33. OECD ibid. at p.35.

34. Dunning op. cit. n.27 Table 8.1 at p.225 using Young, Hood and Hamill op. cit. n. 32 as source.

35. Dunning op. cit. n.27 at p.226. 
(3) The House of Lords Ruling and Wider Issues:

Domicile

Arguably many of the jurisdictional problems raised by the Cape litigation could be solved by applying the general principle of domicile as the basis of jurisdiction for all cases involving litigation against English based MNEs for the acts of their overseas subsidiaries. ${ }^{36}$ This would have the advantage of predictability as any claimant, wherever he/she may be domiciled, will know that he/she can sue the English domiciled parent in England.$^{37}$ Indeed, it would reduce the wide discretion given to judges when determining the appropriateness or otherwise of the forum, a discretion which, as in this case, led to conflicting findings before different courts thereby increasing costs and uncertainty for litigants. Furthermore, it would accord with an enterprise analysis of the MNE and acknowledge that ultimate managerial responsibility lies with the parent. It would then be for the parent to show, either that one of the exceptions to the domicile principle in the Brussels Convention applies or, at the merits stage, that, on the facts of the case, it had no part in, or control over, the acts of its affiliate that have led to the harm complained of. ${ }^{38}$

The extension of the Brussels Convention approach to establishing jurisdiction to cases involving non-Convention countries may be objected to, first, on the ground that it creates a presumption of parent company responsibility that is inappropriate for the issue of jurisdiction in that it confuses jurisdiction to adjudicate and jurisdiction to prescribe and, furthermore, conflates the issue of jurisdiction with that of substantive liability. ${ }^{39}$ This point can be answered by the fact that the requirements for establishing the domicile of the parent are factually distinct from those

36. By Article 53 of the Brussels Convention the domicile of a company, or other legal person or association of persons, will be determined, for the purposes of the Convention, by reference to its seat. In order to determine that seat the court shall apply its rules of private international law. As English law did not determine the domicile of a company in accordance with the seat theory, preferring the incorporation theory, the 1982 Act introduced a definition of the seat of a company that allowed for this theory to be used in Convention cases. Thus a company or association has its seat in the United Kingdom if, and only if, it is incorporated or formed under the law of a part of the United Kingdom and has its registered office or some other official address in the United Kingdom, or its central management and control is exercised in the United Kingdom: Civil Jurisdiction and Judgments Act 1982 s.42(3).

37. Note the Opinion of the European Court of Justice of 13 July 2000 in Case C-412/98 Societe Group Josi Reinsurance Company SA v. Compagnie d'Assurances Universal General Insurance Company where the Court held that the system of rules for the conferment of jurisdiction established by the Convention is not usually based on the criterion of the plaintiff's domicile or seat. The Court went on to note that neither is the system based on the nationality of the parties. See further text at nn.45-6.

38. On which see further Muchlinski op. cit. n.2 chap.9.

39. See Institute of International Law Yearbook Vol.65 part I, Session of Milan 1993, Preparatory Work, p.306-7.(Paris, Editions A. Pedone). 
that will establish its substantive liability for the acts of its overseas affiliate. Thus the risk of confusion between jurisdictional issues and the merits of the case should not be overstated. Indeed, the adoption of the domicile principle will simplify the jurisdiction issue, and allow the parties to move more quickly to the substantive question of liability, at which point the alleged control of the parent for the acts of its overseas subsidiaries will be tested.

The second objection concerns the effect of the Court of Appeal's widely criticised decision Re Harrods (Buenos Aires) $\mathrm{Ltd}^{40}{ }^{40}$ In that case the Court decided that the domicile principle in the Brussels Convention has no application to cases where there is a choice of jurisdiction between the English forum and the courts of a non-Convention country. In such a case the forum non conveniens doctrine will apply by virtue of Article 49 of the Brussels Convention. In the course of its judgment the Court of Appeal overruled two first instance decisions where it was held that Article 2 of the Brussels Convention introduced a mandatory requirement to use domicile as the basic principle of jurisdiction and that it excluded the doctrine of forum non conveniens. ${ }^{41}$ The decision of the Court of Appeal has since been followed in a number of subsequent cases. ${ }^{42}$ The question whether this case was correctly decided was raised by the claimants in the appeal to the House of Lords. They sought to persuade their Lordships' House either to distinguish the case, or to overrule it, or to refer the issue to the European Court of Justice. ${ }^{43}$

Preferring to base their decision on the application of the Spiliada doctrine to the facts of the case, their Lordships were unwilling to respond to the extensive argument put by the parties on this question. However, as Lord Bingham pointed out, had it been necessary to deal with the issue, a reference to the European Court of Justice (ECJ) would have been necessary as his Lordship did not consider the issue to be clear. ${ }^{44}$

Whether this is so may be open to discussion. In the light of the recent Opinion of the European Court of Justice (ECJ) in the case of Group Josi Reinsurance Company SA v. Universal General Insurance Company, ${ }^{45}$ the continuing validity of the position taken by the Court of Appeal in $R e$ Harrods may be open to doubt. In that case the ECJ held that the Brussels Convention is in principle applicable where the defendant has its domicile

40. [1992] Ch 72; [1991] 4 All E.R. 334 (CA). For criticism see Cheshire and North op. cit. n.3 at pp.264-6.

41. S \& W Berisford plc v. New Hampshire Insurance Co [1990] 2 Q.B. 631; Arkwright Mutual Insurance Co Ltd v. Bryanston Insurance Co Ltd [1990] 2 Q.B. 649.

42. The Po [1991] 2 Lloyds Rep. 206 (CA); The Nile Rhapsody [1994] 1 Lloyds Rep. 382

(CA); Sarrio SA v. Kuwait Investment Authority [1997] 1 Lloyds Rep. 113 (CA);

Haji-Ioannou v. Frangos [1999] 2 Lloyds Rep. 337 (CA).

43. See House of Lords, Claimant's Final Served Case pp.19-32.

44. Schalk Willem Burger Lubbe et al. v. Cape plc op. cit. n.5 at p.394.

45. See n.37. 
or seat in a Contracting State, even if the plaintiff is domiciled in a non-member country, save where the Convention itself provides that the jurisdiction which it sets out is dependent on the plaintiff's domicile being in a Contracting State. In the Court's view,

[t]he Convention enshrines ... the fundamental principle that the courts of the Contracting State in which the defendant is domiciled or established are to have jurisdiction.... [I]t is only by way of exception to that general rule that the Convention includes certain specific provisions which, in clearly defined cases, accord an influence to the plaintiff's domicile. It follows that, as a general rule, the place where the plaintiff is domiciled is not relevant for the purpose of applying the rules of jurisdiction laid down by the Convention, since that application is, in principle, dependent solely on the criterion of the defendant's domicile being in a Contracting State. Consequently the Convention does not, in principle, preclude the rules of jurisdiction which it sets out from applying to a dispute between a defendant domiciled in a Contracting State and a plaintiff domiciled in a non-member country. ${ }^{46}$

The basis of the Court of Appeal's ruling in Re Harrods appears to have been the rather tenuous connection between the English registered company and the English jurisdiction. Harrods (Buenos Aires) Ltd was incorporated in England in 1913 and its registered office had always been in England. It is what business historians would call a "free-standing" company. Much British business undertaken before 1914 would be conducted through companies floated on the London capital market to undertake overseas activities. ${ }^{47}$ Although the precise organisation of such companies remains a matter of debate, the location of financial operations with the head office in England cannot be easily overlooked. Apart from anything else it must create a strong presumption that English incorporation has been chosen so that English law can regulate the organisation and conduct of the company. The logic behind the Harrods case is that the initial decision by the company's promoters to incorporate in England will be disregarded where the court, in its discretion, feels that the company is really operating elsewhere. This may amount to unwarranted interference in the legal organisation of MNEs. If the promoters and owners of the company fail to move the place of incorporation to the country in which the real seat of management exists, the courts should not do this for them. Furthermore, the approach taken in Re Harrods also has serious implications for the amenability of network companies to jurisdiction, where these split their management functions across several jurisdictions. By so doing are they able to defeat the effect of English

46. Ibid. paras.53-59.

47. See Geoffrey Jones The Evolution of International Business (London, Routledge, 1996) pp.34-5. 
incorporation and avoid jurisdiction here on the ground that they do not perform the bulk of the central control or management function here?

A final objection might be that the grant of a general jurisdiction over English domiciled companies will give rise to a risk, which Lord Hoffmann foresaw in Connelly v. RTZ, in that the mere presence of a parent company in England will expose a multinational to liability to be sued here in respect of activities anywhere in the world. ${ }^{48}$ This matter was not touched upon in the House of Lords in the Cape case. Indeed, the risk of a global jurisdiction to litigate against English based MNEs in England should not be overstated. It ignores the possibility of the defendant parent company invoking one of the exceptions to domicile-based jurisdiction recognised in the Brussels Convention, or to show that the parent is not a proper party to the proceedings and that the case against it should be struck out. However, that is a rather unlikely situation where lawyers are acting for claimants on a conditional fee basis, as they would not risk wasting time and money on a basically unarguable case. Equally, the Community Legal Service is likely to take a dim view of any law firm that has put forward such a case and may approach future applications for legal aid with greater scepticism. Furthermore, the position taken by Lord Hoffmann assumes that there is no English public interest in acting as a forum for litigation concerning the overseas activities of English based MNEs. This last point will be considered further in the next sub-section.

\section{Appropriateness of the Forum}

The Relevance of Corporate Organisation

Where an equity-based group is involved, as is the case in the Cape litigation, the characterisation of the cause of action will be significantly affected by the existence of separate corporate entities. Therefore, in a case involving personal injuries suffered at the hands of an overseas subsidiary, it would be easy to characterise the issue as one arising out of the activities of the subsidiary alone, and, in the process, to ignore the nature of the group enterprise carried on by parent and subsidiary together. Once such a view of corporate organisation is accepted, it becomes very hard to show that other factors relevant to a forum non conveniens analysis point in any way other than to the forum of the host country in which the subsidiary is located. ${ }^{49}$ Arguably, this is the approach that was taken by the Court of Appeal in the second appeal when deciding to stay the English proceedings. On the other hand, the first Court of Appeal reformulated the principal issue in the case as follows:

48. [1997] 4 All E.R. 335 at 349c.

49. This is what happened in In re Union Carbide etc op. cit. n.16. See Muchlinski op. cit. n.16 for details of the plaintiff's evidence of group organisation. This was based on Union Carbide's corporate practice manuals that had been disclosed in pre-trial discovery. 
Whether a parent company which is proved to exercise de facto control over the operations of a (foreign) subsidiary and which knows, through its directors, that those operations involve risks to the health of workers employed by the subsidiary and/or persons in the vicinity of its factory or other business premises, owes a duty of care to those workers and/or other persons in relation to the control which it exercises over and the advice which it gives to the subsidiary company.

As a result the first Court of Appeal decision did stress the international nature of Cape's operations and this led it to be more reluctant to accept the defendant's contention that England was not a proper forum for the action.

The House of Lords approached this matter with caution. In his leading judgment, Lord Bingham points out that the issues in these cases fall into two segments. ${ }^{50}$ The first segment concerns the responsibility of the defendant as a parent company for ensuring the observance of proper standards of health and safety by its overseas subsidiaries. Resolution of this issue is likely to involve inquiry into what part the parent played in controlling the operations of the group, what its directors and employees knew or ought to have known, what action was taken or not taken, whether the defendant owed a duty of care to the employees of the group and whether that duty was broken. Much of the relevant evidence would be found at the offices of the parent company, including minutes of meetings, reports by directors and employees on overseas visits, and correspondence. The second segment involves the personal injury issues relevant to each individual: diagnosis, prognosis, causation (including third party contribution to the plaintiffs' condition) and special damage. This would involve examination of each individual plaintiff and an inquiry into his or her working or living conditions for the period in question.

In this light there was some justification in each of the decisions of the lower courts. Thus, the first instance decision, which led to the first Court of Appeal case, was not untenable when the judge, Mr Kallipetis QC, considered that the balance of convenience of trying personal injury issues in South Africa outweighed any benefit in trying the parent company responsibility issue here. Equally, the first Court of Appeal's assessment that the balance lay with the parent company responsibility issue here was not unreasonable or wrong. Furthermore, Buckley $\mathrm{J}$ and the second Court of Appeal were not wrong to hold that the personal injury issues were more significant, especially after the emergence of over 3,000 new plaintiffs following the first Court of Appeal decision.

Therefore, the House of Lords would not be drawn on the issue of characterisation. This leaves open some basic questions about the

50. Op. cit. n.5 at pp.390-391. 
implications of the corporate separation between affiliated entities. That requires a brief excursion into corporation law, especially as a major justification for the separate treatment of these entities concerns the preservation of limited liability. According to Professor Blumberg, the extension of limited liability to corporations pre-dates the rise of integrated national and multinational corporate groups. ${ }^{51}$ As such it is a device for the protection of the ultimate human and institutional shareholders. It was never envisaged as a means of insulating from liability separately incorporated entities within the same enterprise. Indeed, one effect of such an extension of limited liability is to shift the risk of liability onto the involuntary creditors of the group, the clearest example being victims of torts committed by the group enterprise in the course of its operations. This goes well beyond the acceptable consequences of limited liability, especially where the economic process that gives rise to the injuries is carried on as a single enterprise within the group.

In response, it may be argued that such protection is needed to ensure that the group will take on the risk of the enterprise. This argument assumes that the activities of the group involve new and risky investment. This should be distinguished from a mere re-organisation of the existing business. Consequently, where, as in the Cape cases, the investment in South Africa involved the setting up, after World War II, of new subsidiaries to run the asbestos operations, this was not a "new" investment, but a corporate restructuring. The underlying "firm" remained the same. ${ }^{52}$ Furthermore, where new investment does occur the cost of deterring that investment must be balanced against the cost of externalising the risk to involuntary creditors. ${ }^{53}$ In relation to the Cape cases, it is not immediately obvious why the cost of dealing with asbestos related injuries should be borne exclusively by the local subsidiary alone, which may not have the funds to compensate all the claimants, and which in turn shifts this cost onto the claimants themselves. This may be tolerable in a country where most of the claimants will be insured against such risks, though this, in its turn, raises the spectre of moral hazard on the part of the enterprise. ${ }^{54}$ However, on the facts of the Cape cases, such insurance does not exist and so the only avenue for adequate compensation is the suit against the company alleged to have acted negligently.

51. Blumberg op. cit. $\mathrm{n} .1$ chap.6 on which this analysis is based.

52. Blumberg op. cit. n.1 at p.131.

53. Ibid.

54. Surely, if a firm is undertaking hazardous industrial activities it must be prepared to take on at least part of the risk, given that if it does not it will have a greater incentive to act in a negligent way. Furthermore, if it is willing to take all the profit on the venture the enterprise must carry some of the associated risk. 
How that company is defined for jurisdictional purposes will be decisive. To ignore the integrated multinational enterprise in such cases appears not only to misuse the doctrine of corporate separation for the purposes of the underlying liability issue, but also serves to justify adding a "jurisdictional veil" over and above the "corporate veil" as a protection against liability for the parent company. It is the underlying "corporate veil" between parent and subsidiary that allows the "jurisdictional veil" to be raised.

It might be argued that existing principles of tort liability allow for parent liability in appropriate cases, without upsetting the principle of corporate separation, in that the parent can always be shown to be a direct tortfeasor alongside the subsidiary. Thus the parent may be introduced into the action as a proper party to the proceedings. That may be the case in relation to substantive liability. However, to the extent that jurisdiction is in issue, so long as the principle of corporate separation is applied strictly it may be very hard indeed to show that the parent is a proper party to tort proceedings which arise in a foreign host country and cause harm to foreign claimants. ${ }^{55}$ It is equally a problem in relation to subsequent enforcement of foreign judgments which may disregard the legal separation between parent and subsidiary. ${ }^{56}$

In the Cape case the second Court of Appeal decision takes a traditional view of parent company responsibility for the acts of its overseas subsidiaries, allowing the court to ignore evidence as to the role of the parent company, which, according to the claimant's case, must have known of the risks associated with asbestos mining and production at the time of the alleged harm. ${ }^{57}$ Thus a vital part of the case can be made harder to argue, as the principal location for evidence of parent company policy and practice, and for the principal witnesses among senior management, is the English home country forum, not the host country forum of South Africa. That much is accepted by Lord Bingham in his analysis of the "first segment" of the case. In this respect the first Court of Appeal decision in Cape was correct as it did not preclude such issues from being put. The claimants have put their case on this ground, they have chosen the English forum as of right and their choice cannot be easily overturned under the Spiliada doctrine. It is for the defendant to show first that the foreign forum is available and is clearly more appropriate than the English forum, not for the claimant to justify the continuation of the English proceedings. That would be to reverse the burden of proof under Spiliada.

55. See Multinational Gas and Petroleum Services Co v. Multinational Gas and Petroleum Services Ltd [1983] Ch. 258 (CA).

56. See Adams v. Cape Industries [1990] Ch. 433 (CA)

57. See Claimants Final Served Case op. cit. n.43 at pp.43-50. 
"Equality of Arms" Issues

The voluntary submission by Cape plc to the South African jurisdiction raised the question of how the courts should interpret such action. The claimants asserted that this was no more than a case of "reverse forum shopping" in that a MNE was attempting to force the selection of a forum more favourable to its case at the expense of the claimants' choice.$^{58}$ This argument was rejected by the House of Lords. Giving the judgment of the House on this issue, Lord Hope, after a review of early Scottish authorities that underlay the principles in the Spiliada doctrine,${ }^{59}$ held that:

The ground on which the jurisdiction of the courts in the other forum is available to be exercised is of no importance either one way or the other in the application to the case of the Spiliada principles.

This reasoning is hard to accept against the background of the parties' disparate resources. Here, the views of the South African Government in its submissions to the House of Lords are significant. ${ }^{60}$ The Republic doubted whether South Africa was an appropriate forum for the Cape cases, given that the defendant company is an English company and was sued as of right before the English courts. Furthermore, the Republic stressed that South Africa was an alternative forum only because of the choice made by Cape. Indeed, Cape had no assets in South Africa for over 20 years. However, by submitting to South African jurisdiction, it would have control over the litigation in that, as South African law did not contain the forum non conveniens doctrine, the claimants could not choose the forum. In the view of the South African government, it was undesirable as a matter of public policy that one party to the litigation should be able to elect its forum in this way, when it could decline to elect to do so in an identical future case. ${ }^{61}$ Furthermore, as the editors of Dicey and Morris point out, if the jurisdiction of the foreign court is open to a claimant only if the defendant undertook to submit, and later did submit, to its jurisdiction, that court is not available in the material sense. It follows that an undertaking by the defendant to submit to the jurisdiction of the foreign court cannot make the foreign court available if it would not have been so without his undertaking. ${ }^{62}$ Regrettably, this point is not addressed by their Lordships and so the decision leaves open the possibility of tactical "reverse forum shopping" by MNEs. That is

58. See Claimants Final Served Case ibid. at pp.35-40.

59. Lord Hope cited Clements v. Macaulay (1866) 4 M. 583; Societe du Gaz de Paris v. Societe Anonyme de Navigation "Les Armateurs Francais" [1925] S.C. 332; Tulloch v. Williams (1846) 8 D. 657; Sim v. Robinow (1892) 19 R. 665.

60. See Statement of Case on Behalf of the Republic of South Africa, 26 May 2000.

61. Ibid. para.2.2.

62. Dicey and Morris Conflict of Laws (13th ed, 2000) para.12-023. 
particularly problematic in cases, such as the Cape cases, where claimants do not enjoy the same resources as the defendant corporation..$^{63}$ The courts should protect such claimants against this risk. Indeed, that would be consistent with the Brussels Convention, which would give EU-based claimants in tort cases arising within the EU, involving harm allegedly caused by the integrated network of the MNE, the choice between the host country forum, where the harm occurred, and the home country, where the parent is domiciled, and where the decisions leading to the alleged harm may be said to have arisen. ${ }^{64}$

The claimants repeated a number of other specific grounds, first aired before the second Court of Appeal, upon which to challenge Cape's choice of South African forum on the basis that these created an inequality of access to justice between the parties. ${ }^{65}$ This position was given greater weight by the intervention of the South African Government in the appeal to the House of Lords where the same points were repeated. ${ }^{66}$ The House of Lords accepted these arguments. ${ }^{67}$ According to Lord Bingham, the proceedings could now only go forward as a group action. Furthermore, the complexity of the issues required the intervention of professional lawyers and experts. That would represent a considerable expenditure of financial resources and manpower in South Africa. However, legal aid was clearly unavailable in South Africa, and the claimants' contention that contingency fee arrangements were very unlikely to be entered into by South African lawyers was accepted. Thus the probability was that, if these proceedings were stayed in favour of the South African forum, the plaintiffs would have no means of obtaining the necessary professional representation and expert evidence. That would amount to a denial of justice. That provided a compelling ground under the second stage of the Spiliada test for refusing to stay proceedings in England. The conclusions of the second Court of Appeal had failed to take account of the evidence, which did not permit the finding which the court made. Furthermore, the absence of a group action procedure in South Africa was not compelling on its own but it served to reinforce the claimants' case especially as it increased the uncertainty surrounding the applicable procedure. Moreover, the question of causation and the role of

63. Whether the same approach should be taken in litigation involving parties of equal resources is open to further discussion. Here different considerations may apply as the parties may be equally able to conduct litigation in a variety of alternative fora.

64. See Brussels Convention op. cit. n.3 Article 5(3) and Case 21/76 Bier BV v. Mines de Potasse D'Alsace SA [1976] E.C.R. 1735. The ECJ held that Article 5(3) is intended to give the claimant the option of suing either in the place where the damage occurred or the place of the event giving rise to it.

65. See text at nn.21-5 and Claimants Final Served Case at pp.62-117.

66. See Statement of Case on Behalf of the Republic of South Africa, 26 May 2000 paras.4.11-4.15.

67. Op. cit. n.5 at pp.391-394. 
third parties, while pointing to the South African forum, did not lead to a conclusion that the defendants would be prejudiced, so long as new claimants followed the existing claimants' undertakings in this matter.

The claimants put a further argument, saying that the stay of English proceedings may involve a breach of Article 6 of the European Convention on Human Rights in that a decision to remove the case to South Africa may deprive the claimants of their right to a fair trial in the determination of their civil rights and obligations, which include questions relating to negligence liability ${ }^{68}$ The House of Lords did not pronounce on the matter. Lord Bingham merely noted that Article 6 did not support any conclusion which was not already reached on application of the Spiliada principles. ${ }^{69}$

This part of the case raises a wider question affecting the "equality of arms" between the parties. According to the European Court of Human Rights, in respect of litigation involving opposing private interests, "equality of arms implies that each party must be afforded a reasonable opportunity to present his case-including his evidence-under conditions which do not place him at substantial disadvantage vis-à-vis his opponent". ${ }^{70}$ This has serious implications in relation to litigation between MNEs and individual claimants in personal injury cases. First, the right to present the evidence by a party may have implications for the exercise of discretion over jurisdiction. It may curtail the freedom of the court to characterise an issue involving MNE group liability for the acts of a subsidiary as one involving the latter entity alone, where this results in a finding of no jurisdiction. By such reasoning important issues of evidence showing group liability will be excluded from the court, especially where there is no effective alternative forum that is willing to take on the litigation. Secondly, as already noted, in personal injury cases, especially those where there is no insurer involved, the claimants are very unlikely to have the same resources as the MNE in relation to the conduct of litigation. In a democratic society based on the rule of law, this places a duty on the courts to ensure that such differences between the parties do not impact adversely on the ability of the individual claimants to have a fair hearing of their case. Therefore, factors of the kind identified by the claimants in relation to the South African legal system, which materially impact on the economic ability of the claimants to pursue their claims, must be given significant weight under the substantial justice aspect of Spiliada. The effect on the claimants was much the same as the absence of legal aid was on the claimant in Connelly. Thus the House of Lords

68. See Axen v. Federal Republic of Germany ECtHR Ser A 72 (1983).

69. Op. cit. n.7.

70. Dombo Beheer v. Netherlands ECtHR Ser.A. 274 at para.33 (1993) 
appears to be adding an "equality of arms" requirement to the Spiliada doctrine as part of a wider due process element.

\section{The Public Interest Issue}

This aspect of the Cape cases raises the question of whether the American "public interest factors" analysis has any place in the Spiliada doctrine. The South African government's submission denied that there was any public interest in litigation before its courts. In the first place, the public interest pointed to the English forum in view of the strong presumption under the Spiliada doctrine that the defendant's domicile is the appropriate forum and the high burden of proof on the part of the defendant to establish a clearly more appropriate forum. Furthermore, Cape now had no connection with South Africa and no assets there. Thus the nexus between Cape and the English courts was stronger than the nexus between that company and the South African courts. ${ }^{71}$ Secondly, significant weight should be given to the question of applicable law. In the South African government's opinion, the central issue was whether there was negligence on the part of Cape's management in the face of known safety hazards. The primary law governing this issue would appear to be the English law of negligence. The applicable South African laws at the times of the events complained of afforded lesser treatment to black workers, such as the claimants in these proceedings. These laws were racially discriminatory as between white and black workers on issues such as medical care and compensation and, as such, were unconscionable and should play no part in determining Cape's duties, or the scope of the law of negligence, even if South African law applied. ${ }^{72}$ Thirdly, there was a fundamental difference between the American and English perceptions of the public interest issue which made the American case-law, culminating in the Bhopal litigation, ${ }^{73}$ inapplicable or at least distinguishable. In the first place, the American cases on this issue were all concerned with keeping out of American courts disputes against American companies which involved events and harm outside the United States. The American courts would not afford a foreign plaintiff's choice of American forum the same deference that would be accorded to such a choice by an American plaintiff. $^{74}$ Furthermore, since most U.S. cases focused on inter-state rather than international cases, the issue was more one of convenience than appropriateness. ${ }^{75}$ Moreover, the Bhopal case could be distinguished from the present case. At the time of the Bhopal litigation

71. Op. cit. n.60 paras.3.1-4.4.

72. Ibid. para.4.5.

73. See n.16 above.

74. South African Government Statement of Case op. cit. n.60 para.4.16 and see too Muchlinski op. cit. n.16 above at p.554.

75. Ibid. 
India was a democracy and had a strong interest in reviewing the environmental standards to be applied in establishing liability through its own courts. The litigation related to violations of Indian laws which were in force and the Indian plant had been regulated by a number of Indian agencies which continued to exist and operate when the matter came to court. By contrast the South African litigation related to racially discriminatory laws which no longer existed and to an industrial and regulatory context which was set in South Africa's colonial history and under the apartheid regime, neither of which were of immediate relevance to the present position. ${ }^{76}$

In the event the House of Lords rejected the view that public policy questions, of the kind considered in the Bhopal litigation, had any role to play in the Spiliada doctrine. Lord Bingham stated that, "in applying this principle questions of judicial amour propre and political interest or responsibility have no part to play." 77 According to Lord Hope, who gave the leading judgment on this point, the doctrine of forum non conveniens left no room for considerations of public interest or public policy which could not be related to the private interests of the parties or the ends of justice in the case which was before the court. The courts were simply not equipped to conduct the kind of inquiry and assessment of the international as well as domestic implications which would be needed to follow that approach. ${ }^{78}$

\section{(4) Concluding Remarks}

The House of Lords decision in the Cape cases represents a major development in the law relating to jurisdiction over the overseas activities of English based MNEs. First, the decision clearly introduces a due process element into the second stage of the Spiliada analysis, and adds to the Connelly decision, in showing that the stay of English proceedings, begun as of right before an English court, will not be granted where the claimants will face serious obstacles to the conduct of litigation in the foreign forum of a kind which are likely to mean that no trial of the action will ever take place. However, their Lordships' insistence that the voluntary submission of Cape to South African jurisdiction was not a material consideration in relation to the availability of an alternative forum, somewhat weakens the protection that the law can give to individual claimants in such cases, given that the practical effect of Cape's submission would have been to allow Cape to take advantage of the

\footnotetext{
76. South African Government Statement of Case op. cit. n.60 paras.5.1-5.6

77. Op.cit. n.5 at p.394.

78. Ibid. at pp.397-398.
} 
resulting inequality of arms between itself and the claimants. It may have been preferable simply to say that such submission is not evidence of an available alternative forum, along the lines suggested by the first Court of Appeal and by the editors of Dicey and Morris. The current situation still leaves it open to MNEs to engage in reverse forum shopping, and to force claimants to justify their choice of English forum, through the simple expedient of submitting voluntarily to the host country jurisdiction.

Secondly, although the House of Lords decision does not accept enterprise analysis as such in relation to the characterisation of the underlying issue from which the Spiliada test commences, there is none the less an acceptance that transnational personal injury cases, brought against English based MNEs, can raise matters of parent company responsibility for the acts of their overseas subsidiaries, where the parent controls the subsidiary's operations in the relevant area of activity through its system of decision-making and managerial supervision. Thus the decision leaves open the possibility for an enterprise based characterisation of issues involving the responsibility of parent companies in multinational groups. This approach will help to weaken the grip of the traditional analysis of transnational personal injury cases as involving only the subsidiary and the local claimants. However, a final determination of this issue awaits in future cases. Whether future courts will develop an enterprise analysis depends on how they see their function in such cases, and on whether they will be prepared to extend English jurisdiction to the overseas operations of English based MNEs merely on the ground that the overseas forum is not clearly more appropriate given the managerial organisation of the enterprise. In this the courts will have to consider issues of public policy, despite the apparent rejection of such an approach by the House of Lords.

This, in turn raises a third set of issues. Will the English courts be able to avoid the wider policy questions raised by the overseas operations of English based MNEs? That is open to debate. The argument put by the claimants and the South African government raised a wider issue as to the public interest of the home forum. The conditions of black South African workers were of significant public interest in England during the years of apartheid in South Africa. At the time Cape was aware of such sentiment. ${ }^{79}$ Indeed, this issue was an early major instance in which the question of the complicity of corporations with host country policies which violated fundamental human rights was raised. Since that time, the recently revised OECD Guidelines on Multinational Enterprises assert that, "[g]overnments adhering to the Guidelines encourage the enterprises operating on their territories to observe the Guidelines wherever they operate, while taking into account the circumstances of each host 
country" ${ }^{80}$ This suggests that the courts of the home country should take into account the contents of the Guidelines when asked to consider the legality of the overseas operations of home based firms, while paying due respect for the right of the host country to regulate the conditions under which such firms operate upon their territory.

There are certain substantive provisions in the Guidelines that are of relevance to the Cape cases. Under the "General Policies" Guideline, enterprises are exhorted to "respect the human rights of those affected by their activities consistent with the host government's international obligations and commitments". Under the "Employment and Industrial Relations" Guideline enterprises should, within the framework of applicable law, regulations and prevailing labour relations and employment practices, inter alia "not discriminate against their employees with respect to employment or occupation on such grounds as race, colour, sex, religion, political opinion, national extraction or social origin..." and "take adequate steps to ensure occupational health and safety in their operations" ${ }^{81}$ In this, the Employment Guideline echoes the relevant provisions of the 1998 ILO Declaration on Fundamental Principles and Rights at Work and the 1977 ILO Tripartite Declaration of Principles Concerning Multinational Enterprises and Social Policy. ${ }^{82}$ Thus, in one of the most recent internationally accepted statements on the general obligations of MNEs, it is clear that the kinds of issues raised by the South African government in the context of the Cape cases are of central importance. Although the OECD Guidelines are non-binding, they do represent a consensus on what constitutes good corporate behaviour in an increasingly global economy. Furthermore, they are clear that home countries of MNEs have a moral duty to ensure that the standards contained in the Guidelines are maintained world-wide. Given that the United Kingdom adheres to the OECD Guidelines as a member of that organisation, in future the English courts may have to pay heed to their contents when determining issues of public interest in litigation involving MNEs. It is open to question whether the English courts can indefinitely refuse to address public interest issues, and hide behind the apparently apolitical doctrine of forum non conveniens, while at the same time coming to decisions that are doubtless informed by such considerations.

Finally, the House of Lords decision refused to deal with the question whether the forum non conveniens doctrine should be replaced by the general principle of domicile, as developed in the Brussels Convention, so that English law relating to jurisdiction could be the same whether the

\footnotetext{
80. OECD Guidelines for Multinational Enterprises, 27 June 2000, "Concepts and Principles" para.2. http://www.oecd.org/daf/investment/guidelines/mnetext.htm 81. Ibid. at p. 4 and 5.

82. OECD Guidelines for Multinational Enterprises: 2000 Review, Commentaries, 27 June 2000 para.20. http://www.oecd.org/daf/investment/guidelines/mnetext.htm
} 
overseas claimant comes from a Convention or a non-Convention country. Given the considerable advantages that may follow from this position, as discussed earlier, and given the serious problems associated with the reasoning in the Re Harrods (Buenos Aires) Ltd case, it is to be hoped that the issue will be resolved in due course by the overruling of this case and the establishment of the Brussels Convention principles as binding rules. On the other hand, should the forum non conveniens doctrine survive in a future multilateral convention on civil jurisdiction and judgments, and the English courts might respond by preserving $R e$ Harrods (Buenos Aires) Ltd, then the enterprise-based analysis put forward in this paper should be followed in relation to the application of the doctrine, so as to avoid the denial of English jurisdiction against English-based parent companies on the basis of a false, or at best incomplete, characterisation of the underlying issues. That should reinforce the protection given to weaker claimants by the decision of the House of Lords under the second limb of the Spiliada doctrine. This would render the type of argumentation that occurred in the Cape case otiose, as the question of jurisdiction could be quickly determined under the first limb, so long as it could be shown that the English domiciled parent was at the head of an integrated group which controlled the subsidiaries operating in the host country where the alleged harm had occurred. 